\title{
ホルツァ法に基づくフレキシブルマニピュレータの 動力学モデリング
}

近野敦* 内 山 勝*

\section{Modeling of a Flexible Manipulator Dynamics Based on the Holzer's Method}

\author{
Atsushi Konno* and Masaru Uchiyama*
}

\begin{abstract}
In this paper, we discuss the modeling of flexible manipulators. In the modeling of flexible manipulators, there are two approaches: one is based on the distributed-parameter modeling and the other on the lumped-parameter modeling. The distributed-parameter model is effective for simple flexible manipulators such as a one-link planar manipulator. For flexible manipulators with multi-link and multi-DOF (degree-of-freedom), however, the distributed-parameter model will be too complicated to use in control. In this paper, we propose a new model for the flexible manipulators based on the lumped-parameter model. Our model is simple enough to construct and implement in control schemes. This model can also be easily applied to manipulators which have flexibility at their joints. Based on our model, dynamic equations of motion are derived by the Lagrange's method. The effectiveness of our model is shown by comparing simulation results with the experimental results.
\end{abstract}

Key Words : Flexible Manipulator, Kinematics, Dynamics, Modeling, Lumped-Parameter Model

\section{1.はじめに}

宇宙で用いられるロボットマニピュレータは，それ自身の質 量に対して可搬質量が非常に大きい，アクチュエータ以外の部 分は非常に軽量化されているなどの特徵をもつ。このようなマ ニピュレータでは，アーム部またはジョイント部の柔軟性を考 慮する必要がある．このような柔軟で, 軽量のフレキシブルマ ニピュレータの研究は 1970 年代頃より盛んに行われるように なった[1].産業用マニピュレータにおいても，高速動作に伴 うアームの振動が問題となっており, フレキシブルマニピュレ ー夕の研究の必要性はますます高まっている.

フレキシブルマニピュレータの動力学解析, 制御則の構築に はどのようなモデルを作成するかが重要なポイントとなる．初 期の研究は, 振動学における弾性体の振動解析法をそのままフ レキシブルマニピュレータに適用したものが多く, 仮定モード 法で近似する方法 [2]や有限要素法によるもの[3][4]が主流 であった. 現在でも多くの研究者がこの立場からモデリングを 行っている[5]〜 [7].

しかし，このようなモデリングは，主として1リンク，また は 2 リンクの平面フレキシブルマニピュレータに応用された が，多リンク多自由度をもつ空間フレキシブルマニピュレータ

\section{原稿受付 1993 年 8 月 23 日}

*東北大学工学部

*Faculty of Engineering, Tohoku University
ではモデルの作成が困難であるばかりではなく，得られたモデ ルに基づく制御則の構築も現実的ではない.このような反省か ら近年は，より簡便で現実的なモデリング手法が提案されてい る[ 8]〜[13].

本論文ではこの路線上で, フレキシブルマニピュレータの新 しいモデルを提案する．従来のモデルは，リンクのたわみ曲線 をいかに近似するかということに力点がおかれ[ 9][10][12]， 剛体マニピュレータとの関連が必ずしも明確ではなかった，提 案するモデルは, 剛体マニピュレータとの関連が明確で, 剛体 マニピュレータのモデルをも包含する．本モデルではすべての マニピュレータはフレキシブルマニピュレータとして取り扱わ れ，剛体マニピュレータは剛性の大きいリンクを有するマニピ ュレータとして表現される.これに基づき, 従来の剛体マニピ ュレータの動力学と本モデルを用いたフレキシブルマニピュレ 一タの動力学との関連について考察する. 最後に, シミュレー ションと実験により，本モデルの有効性を検証する.

\section{2. 集中ばね質量モデル}

弾性体の固有振動数を求める近似解法として, 分布定数系 (連続系)として取り扱う Rayleigh 法, Ritz の方法, Galerkin 法, 仮定モード法, また集中定数系(離散系)として取り扱 j Holzer 法, Myklestad 法, 有限要素法などが知られてい る[14]. 集中定数系の各手法は, 弾性体を幾つかの要素に分割 し，それぞれの要素の振動数方程式を求め, それらをマトリク 
スを用いて足し合わせ，全体の振動数方程式を構築する．ロー 夕のねじり振動の解析法である Holzer 法と，それを梁の曲げ に拡張した Myklestad 法はその要素の分割法に特徴をもつ. 分布定数系の各手法が，比較的密度や重量が均一な系を対象と したのに対し，Holzer 法は細長い軸で連結されたロータのね じり振動系を対象としており [14][15]．このような密度あるい は重量が不均一である系に対して, 非常に有効である. フレキ シブルマニピュレータは, 重量を削ることが難しいアクチュエ 一夕を, 軽量化したアームで連結する構造になっており, Holzer 法や Myklestad 法が対象とした構造によく合致してい る. 本論文では, Holzer 法, Myklestad 法で用いられた集中 ば枚質量モデルをフレキシブルマニピュレータのモデリングに 応用する。

フレキシブルマニピュレータは，アクチュエータにより駆動 されるジョイント(joint)と，それにより結合されたりンク (link)により構成される.ここでは，各ジョイントは回転ジョ イントとし，各リンクの長さは不変とする．まず，問題となる アームを適当な区間に分割する. ひとつのリンクを複数の区間 に分割してもよいし，複数のリンクをひとつの区間と考えても よい．分割した各区間の質量を二分し，それを各区間の両端に 集中質量としてつける. つまり，アームの切断点に集中質量が存 在し，各集中質量間は無質量のばねであると考える. Holzer 法ではこの集中質量部をステーション(station)，無質量のばね 部をフィールド (field) と呼ぶ[14].ここで提案するモデルにお いても，Holzer法にならい，集中質量部をステーション，無 質量のばね部をフィールドと呼ぶことにする．このようにして 作成されたモデルを Fig.1 1 に示す. フレキシブルマニピュレ 一夕は点在する複数のジョイントと集中質量が無質量のばねに よって結合された構造物としてモデル化される.

リンクの分割数を幾つにすればよいかという問題は，適用し ようとするマニピュレータの特性や制御法，あるいはどこまで 精密なモデルが必要かといったことに照らし合わせて決定す る．例えば，非常に柔軟性の大きいリンクを有するフレキシブ ルマニピュレータの場合は, 精度の高い近似モデルを得るため には十分な分割数をとる必要があり，逆に，関節部や先端に大 きな質量が分布し，リンクの質量が非常に小さいマニピュレー 夕の場合は，ひとつのリンクにひとつのフィールドを対応させ ても，十分な近似モデルが得られると考えられる.

フィールドは，ばね定数をもち，両端のステーションまたは ジョイントの間の相対位置関係を与える無質量の弾性梁であ る. Fig. 2 にフィールド $k$ に加わる力とモーメント，及びそ れにより発生する弾性変形を示す. フィールド $k(k=1,2, \cdots$, $q ）$ の変形は，一端の他端に対する相対変位の変化分, ベクト ル $\boldsymbol{s}_{k}$ によって表される，一般に， $\boldsymbol{s}_{k}$ は位置，姿勢の変化を表 す 6 次元ベクトルである．また，全フィールドの弾性変形を表 すつぎのべクトル $\boldsymbol{e}$ を定義する. ベクトル $\boldsymbol{s}_{\boldsymbol{k}}$ を 6 次元とした 場合は $m=6 q$ となる.

$$
\begin{aligned}
\boldsymbol{e} & =\left[\begin{array}{llll}
\boldsymbol{s}_{1}^{T} & \boldsymbol{s}_{2}^{T} & \cdots & \boldsymbol{s}_{q}^{T}
\end{array}\right]^{T} \\
& =\left[\begin{array}{llll}
e_{1} & e_{2} & \cdots & e_{m}
\end{array}\right]^{T}
\end{aligned}
$$

フィールド $k$ の一端にかかる力とモーメントを $\boldsymbol{f}_{k}, \boldsymbol{n}_{k}$ と し, 他端の力とモーメントを便宜上 $\boldsymbol{f}_{k}^{\prime}, \boldsymbol{n}_{k}^{\prime}$ とする. フィール

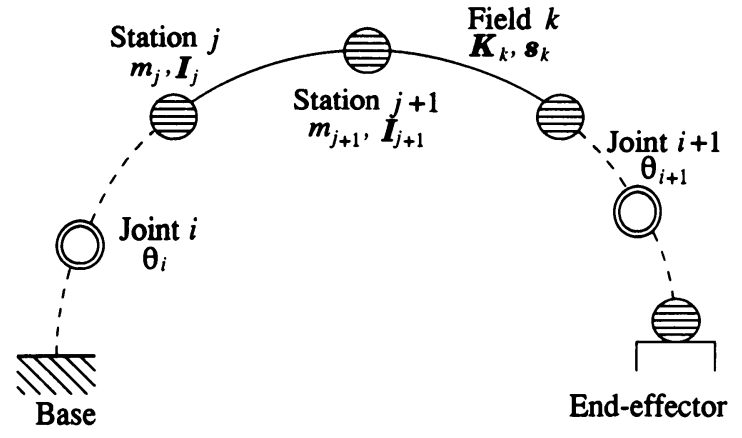

Fig. 1 Lumped-mass and spring model

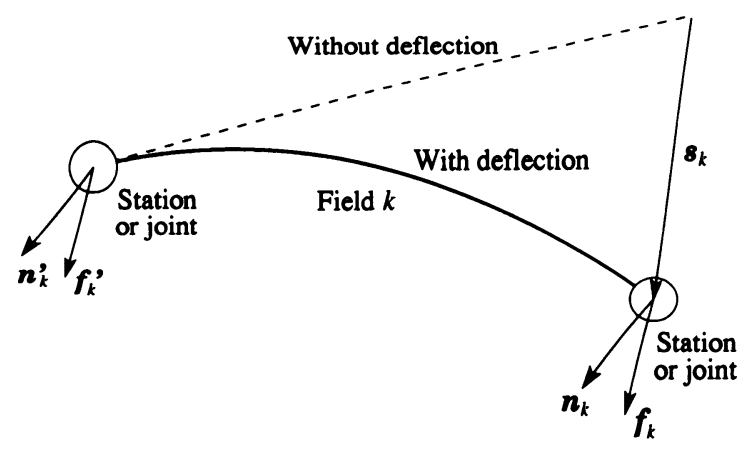

Fig. 2 Forces, moments and deflections at the $k$ th field

ドは無質量であるからフィールドの途中で力とモーメントの入 出力がなければ $f_{k} ， n_{k}$ はそのまま他端へと伝達される. 力と モーメントの釣り合いから $\boldsymbol{f}_{k}^{\prime}, \boldsymbol{n}_{k}^{\prime}$ は容易に求めることができ る.

$\boldsymbol{f}_{k}, \boldsymbol{n}_{k}$ と $\boldsymbol{s}_{k}$ の関係は次式により与えられる

$$
\left[\begin{array}{l}
\boldsymbol{f}_{k} \\
\boldsymbol{n}_{k}
\end{array}\right]=\boldsymbol{K}_{k} \boldsymbol{s}_{k}
$$

ここで， $\boldsymbol{K}_{\boldsymbol{k}}$ は，フィールド $k$ の剛性を表す行列である.

ステーションは，質量と慣性テンソルをもち，フィールドの 端に位置する質点である．ステーション $j(j=1,2, \cdots, p)$ の質量 と慣性テンソルを $m_{j}, \boldsymbol{I}_{j}$ とする。 $m_{j}, \boldsymbol{I}_{j}$ を用いて行列 $\boldsymbol{R}_{j}$ を つぎのように定義する.

$$
\boldsymbol{R}_{j}=\left[\begin{array}{cc}
m_{j} \boldsymbol{E}_{3} & \mathbf{0} \\
\mathbf{0} & \boldsymbol{I}_{j}
\end{array}\right]
$$

ただし， $\boldsymbol{E}_{3}$ は $3 \times 3$ の単位行列である.

ジョイントは, 軸回りの 1 自由度の回転の自由度を有し, 二 つの隣接するフィールドを接続するものとする. ジョイント $i$ $(i=1,2 \cdots, n)$ の回転角を $\theta_{i}$ とし， $\theta_{i}$ よりなる回転角度べクト ル $\boldsymbol{\theta}$ を次式により定義する.

$$
\boldsymbol{\theta}=\left[\begin{array}{llll}
\theta_{1} & \theta_{2} & \cdots & \theta_{n}
\end{array}\right]^{T}
$$

ジョイント, ステーション, フィールドは同一筒所に存在し てもかまわない，例えば，ジョイント部のみに柔軟性をもつマ ニピュレータは，フィールドとジョイントが同一箇所に存在す るとみなすことができる. 


\section{3. フレキシフルルマニピュレータの運動学}

\section{1 座標変換行列}

フィールド $k$ のベース寄りの一端を原点として座標系 $\Sigma_{k}$

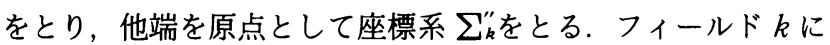
弾性変形がない場合の, $\Sigma_{k}^{\prime \prime} か ゙$ 存在するべき位置に $\Sigma_{k}^{\prime}$ をる (Fig. 3). $\Sigma_{k}$ 及び $\Sigma_{k}^{\prime \prime}$ ，それぞれの原点位置に存在するステ ーションまたはジョイントの特性を表現しやすいように設定す る. 例えば, $\Sigma_{k}$ の原点位置に回転ジョイントが存在する場 合, 回転ジョイントの回転軸方向に $z_{k}$ 軸を, リンクの軸方向 に $x_{k}$ 軸を設定するのはひとつの方法である。

$\Sigma_{k}$ から $\Sigma_{k}^{\prime} へ$ 変換行列を $F_{k}^{\prime}, \Sigma_{k}^{\prime}$ から $\Sigma_{k}^{\prime \prime} へ の$ 変換行列

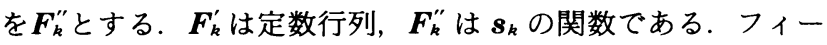
ルドの両端の座標変換行列, つまり $\Sigma_{k}$ から $\Sigma_{k}^{\prime \prime} へ の$ 座標変換 行列 $\boldsymbol{F}_{\boldsymbol{k}}$ は

$$
\boldsymbol{F}_{k}=\boldsymbol{F}_{k}^{\prime} \boldsymbol{F}_{k}^{\prime \prime}
$$

となる． $\boldsymbol{F}_{k}$ をフィールド座標変換行列と呼ぶことにする.

座標変換行列 $\boldsymbol{A}_{i}$ は, ジョイント $i$ に隣接する二つのフィー ルド端の座標系の間の座標変換行列で, ジョイント回転角 $\theta_{i}$ に依存しない座標変換行列 $\boldsymbol{A}_{i}^{\prime}$ と依存する座標変換行列 $\boldsymbol{A}_{i}^{\prime \prime}$ の 積からなる.すなわち

$$
\boldsymbol{A}_{i}=\boldsymbol{A}_{i}^{\prime} \boldsymbol{A}_{i}^{\prime \prime}
$$

である。

また， ステーションjの座標変換行列を $\boldsymbol{S}_{j}$ とする. $\boldsymbol{S}_{j}$ はス テーションに隣接する二つのフィールド端の座標系の間の座標 変換行列で, 定数行列である. $\boldsymbol{S}_{j}$ をステーション座標変換行 列と呼ぶことにする.

ジョイント $i$ とジョイント $i+1$ 間のリンク $i に$ 属するフィ ールド及びステーションの座標変換行列をそれぞれ $\boldsymbol{F}_{i 1}, \boldsymbol{F}_{i 2}$,

$\cdots, \boldsymbol{F}_{i f} ; \boldsymbol{S}_{i 1}, \boldsymbol{S}_{i 2} \cdots, \boldsymbol{S}_{i, f-1}$ とすると, リンク $i$ の座標変換行 列 $\boldsymbol{L}_{i}$ は

$$
\boldsymbol{L}_{i}=\boldsymbol{F}_{i 1} \boldsymbol{S}_{i 1} \boldsymbol{F}_{i 2} \boldsymbol{S}_{i 2} \cdots \boldsymbol{S}_{i, f-1} \boldsymbol{F}_{i f}
$$

となる、

ステーション $j$ のベース側にあって, ステーション $j に$ 最も 近いジョイントとフィールドの番号をそれぞれ， $N_{j}, Q_{j}$ とす ると, ベースからステーション $j$ への座標変換行列 ${ }^{0} T_{j}$ は

$$
{ }^{0} T_{j}=L_{0} A_{1} L_{1} \cdots A_{N j} F_{N^{\prime} j} S_{N^{\prime \prime j}} \cdots F_{Q j}
$$

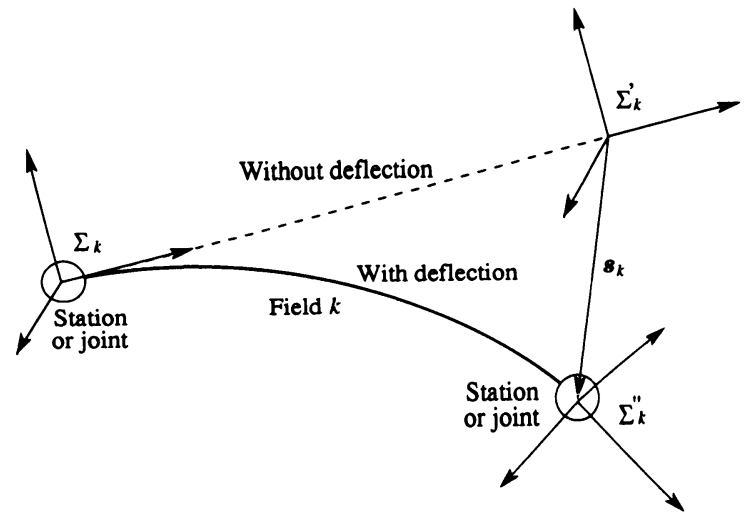

Fig. 3 Coordinate systems at the $k$ th field
となる．ただし， $N_{j}^{\prime}, N_{j}^{\prime \prime}$ は，それぞれ，ジョイント $N_{j}$ のス テーション $j$ 寄りの隣にあるフィールドとステーションの番号 である. 式( 8 )より, ステーション $j$ の位置, 姿勢が $\boldsymbol{\theta}, \boldsymbol{e}$ の 関数として求められる.

\section{2 ステーションの速度, 加速度}

ステーション $j$ の速度ベクトル $\nu_{j}$ を

$$
\boldsymbol{\nu}_{j}=\left[\begin{array}{l}
\boldsymbol{v}_{j} \\
\boldsymbol{\omega}_{j}
\end{array}\right]
$$

により定義する，ただし， $\boldsymbol{v}_{j}, \boldsymbol{\omega}_{j}$ はそれぞれステーションj の速度, 角速度べクトルである. $\nu_{j}$ はジョイントの回転速度 $\dot{\boldsymbol{\theta}}$ とフィールドの弾性変形の速度 $\dot{\boldsymbol{e}}$ を用いて

$$
\nu_{j}=\boldsymbol{J}_{\theta j} \dot{\boldsymbol{\theta}}+\boldsymbol{J}_{\boldsymbol{e}} \dot{\boldsymbol{e}}
$$

と表すことができる．ここで，J $J_{\theta j}, J_{e j}$ はそれぞれ，ステーシ ヨン $j$ の $\boldsymbol{\theta}, \boldsymbol{e}$ に関するヤコビ行列で

$$
\begin{aligned}
& \boldsymbol{J}_{\theta_{j}}=\left[\begin{array}{l}
\boldsymbol{J}_{\theta_{j}}^{v} \\
\boldsymbol{J}_{\theta_{j}}^{\omega}
\end{array}\right]
\end{aligned}
$$

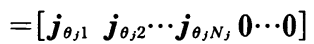

$$
\begin{aligned}
& \boldsymbol{J}_{e_{j}}=\left[\begin{array}{l}
\boldsymbol{J}_{e_{s}}^{v} \\
\boldsymbol{J}_{e_{j}}^{\omega}
\end{array}\right] \\
& =\left[\begin{array}{lll}
\boldsymbol{j}_{e_{s 1}} & \boldsymbol{j}_{e_{2}} \cdots \boldsymbol{j}_{e_{s}, M} \mathbf{0} \cdots \mathbf{0}
\end{array}\right]
\end{aligned}
$$

と表される. $N_{j}, M_{j}$ は，それぞれ，ステーション $j$ のベース 側にあって, ステーション $j に$ 最も近いジョイントの番号, 及 びフィールドの弾性変形成分の番号である. $\boldsymbol{J}_{\theta j}, \boldsymbol{J}_{e j}$ は, 前節 で求めた ${ }^{0} \boldsymbol{T}_{j}$ より，容易に計算することができる， $\boldsymbol{\nu}_{j}$ はまた, つぎのように表すこともできる.

$$
\begin{gathered}
\boldsymbol{\nu}_{j}=\boldsymbol{J}_{j} \dot{\boldsymbol{q}} \\
\boldsymbol{J}_{j}=\left[\begin{array}{ll}
\boldsymbol{J}_{\theta_{j}} & \boldsymbol{J}_{e j}
\end{array}\right] \\
\dot{\boldsymbol{q}}=\left[\begin{array}{c}
\dot{\boldsymbol{\theta}} \\
\dot{\boldsymbol{e}}
\end{array}\right]
\end{gathered}
$$

式(10)の両辺を時間微分するとステーション $\mathrm{j}$ の加速度ベク トル $\dot{\nu}_{j}$ が

$$
\dot{\nu}_{j}=\boldsymbol{J}_{\theta_{j}} \ddot{\boldsymbol{\theta}}+\dot{\boldsymbol{J}}_{\theta_{j}} \dot{\boldsymbol{\theta}}+\boldsymbol{J}_{e j} \ddot{\boldsymbol{e}}+\dot{J}_{e j} \dot{\boldsymbol{e}}
$$

と求められる

\section{4. ラグランジュの運動方程式}

この章ではラグランジュの方法を用いて運動方程式を導出す る. いま，ステーションjの位置を表すべクトルを $\boldsymbol{r}_{j} \in \mathbf{R}^{3 \times 1}$ とする.アームの運動に伴うモータの回転部の運動の影響を無 視すると, アーム全体の運動エネルギー $T$ とポテンシャルエ ネルギー $U$ は，それぞれ，次式により与えられる.

$$
\begin{aligned}
T & =\sum_{i=1}^{n} \frac{1}{2} I_{a i} \dot{\theta}_{i}^{2}+\sum_{j=1}^{p} \frac{1}{2} \boldsymbol{\nu}_{j}^{T} \boldsymbol{R}_{j} \nu_{j} \\
U & =\sum_{k=1}^{q} \frac{1}{2} \boldsymbol{s}_{k}^{T} \boldsymbol{K}_{k} \boldsymbol{s}_{k}-\sum_{j=1}^{p} \boldsymbol{r}_{j}^{T} m_{j} \boldsymbol{g} \\
& =\frac{1}{2} \boldsymbol{e}^{T} \boldsymbol{K} \boldsymbol{e}-\sum_{j=1}^{p} \boldsymbol{r}_{j}^{T} m_{j} \boldsymbol{g}
\end{aligned}
$$

ただし

$$
\boldsymbol{K}=\left[\begin{array}{lll}
\boldsymbol{K}_{1} & & \mathbf{0} \\
& \ddots & \\
\mathbf{0} & & \boldsymbol{K}_{q}
\end{array}\right]
$$

とする. $\boldsymbol{g} \in \mathbf{R}^{3 \times 1}$ は重力加速度べクトル, $I_{a i}(i=1,2, \cdots, n)$ は 
モータの回転部の慣性モーメントである. ラグランジアン $L$ は

$$
\begin{aligned}
L & =T-U \\
& =\sum_{i=1}^{n} \frac{1}{2} I_{a i} \dot{\theta}_{i}^{2}+\sum_{j=1}^{p}\left(\frac{1}{2} \boldsymbol{\nu}_{j}^{T} \boldsymbol{R}_{j} \nu_{j}+\boldsymbol{r}_{j}^{T} m_{j} \boldsymbol{g}\right)-\frac{1}{2} \boldsymbol{e}^{T} \boldsymbol{K} \boldsymbol{e}
\end{aligned}
$$

となる. ラグランジュの運動方程式は次式により与えられる.

$$
\begin{gathered}
\tau_{i}=\frac{d}{d t}\left(\frac{\partial L}{\partial \dot{\theta}_{i}}\right)-\frac{\partial L}{\partial \theta_{i}} \quad(i=1,2, \cdots, n) \\
0=\frac{d}{d t}\left(\frac{\partial L}{\partial \dot{e}_{\imath}}\right)-\frac{\partial L}{\partial e_{\imath}} \quad(l=1,2, \cdots, m)
\end{gathered}
$$

本論文では, 式(21)をリンク運動方程式, 式(22)をフィール ド運動方程式と呼ぶことにする.リンク運動方程式はリンクの 剛体運動を，また，フィールド運動方程式はフィールドの弾性 運動を表す。

\section{1 リンク運動方程式}

式(21)に式(20)の $L$ を代入し，式(13)を考慮し整理する と, 各項は

$$
\begin{gathered}
\frac{d}{d t}\left(\frac{\partial L}{\partial \dot{\theta}_{i}}\right)=I_{a i} \ddot{\theta}_{i}+\sum_{j=\mathrm{P}_{i} \theta}\left(\boldsymbol{j}_{\theta j i}^{T} \boldsymbol{R}_{j} \boldsymbol{J}_{j}\right) \ddot{\boldsymbol{q}} \\
+\sum_{j=P_{i} \theta}^{p} \frac{d}{d t}\left(\boldsymbol{j}_{\theta j i}^{T} \boldsymbol{R}_{j} \boldsymbol{J}_{j}\right) \dot{\boldsymbol{q}} \\
\frac{\partial L}{\partial \theta_{i}}=\frac{1}{2} \frac{\partial}{\partial \theta_{i}} \sum_{j=P_{i}^{\theta}}^{p}\left(\dot{\boldsymbol{q}}^{T} \boldsymbol{J}_{j}^{T} \boldsymbol{R}_{j} \boldsymbol{J}_{j} \dot{\boldsymbol{q}}\right)+\sum_{j=P_{i} \theta}^{p} \frac{\partial \boldsymbol{r}_{j}^{T}}{\partial \theta_{i}} m_{j} \boldsymbol{g}
\end{gathered}
$$

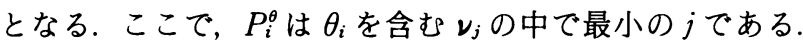
すなわち, ジョイント $i$ のエンドエフェクタ側のステーション で, ジョイント $i$ に最も近いステーションの番号である. ここで

$$
\begin{gathered}
\boldsymbol{j}_{\theta j i}=\left[\begin{array}{l}
\boldsymbol{j}_{\theta j i}^{v} \\
\boldsymbol{j}_{\theta j i}^{\omega}
\end{array}\right] \\
\boldsymbol{g}_{6}=\left[\begin{array}{c}
\boldsymbol{g} \\
\mathbf{0}_{3 \times 1}
\end{array}\right]
\end{gathered}
$$

とすると，

$$
\frac{\partial \boldsymbol{r}_{j}^{T}}{\partial \theta_{i}}=\boldsymbol{j}_{\theta j i}^{v T}
$$

であるから

$$
\frac{\partial \boldsymbol{r}_{j}^{T}}{\partial \theta_{i}} m_{i} \boldsymbol{g}=\boldsymbol{j}_{\theta j i}^{T} m_{j} \boldsymbol{g}_{6}
$$

となる，式(23)，(24)，（28）から式(21)は

$$
\begin{aligned}
\tau_{i}= & I_{a i} \ddot{\theta}_{i}+\sum_{j=P_{i}{ }^{\theta}}^{p}\left(j_{\theta j i}^{T} \boldsymbol{R}_{j} \boldsymbol{J}_{j}\right) \ddot{\boldsymbol{q}}+\sum_{j=P_{i} \theta}^{p} \frac{d}{d t}\left(\boldsymbol{j}_{\theta j i}^{T} \boldsymbol{R}_{j} \boldsymbol{J}_{j}\right) \dot{\boldsymbol{q}} \\
& -\frac{1}{2} \frac{\partial}{\partial \theta_{i}} \sum_{j=P_{i}^{\theta}}^{p}\left(\dot{\boldsymbol{q}}^{T} \boldsymbol{J}_{j}^{T} \boldsymbol{R}_{j} \boldsymbol{J}_{j} \dot{\boldsymbol{q}}\right)-\sum_{j=P_{i}^{\theta}}^{p}\left(\boldsymbol{j}_{\theta j i}^{T} m_{j} \boldsymbol{g}_{6}\right)
\end{aligned}
$$

となる. $i=1,2, \cdots, n$ について上式をまとめると

$$
\begin{aligned}
\boldsymbol{\tau}= & \boldsymbol{R}_{a} \ddot{\boldsymbol{\theta}}+\left(\sum_{j=1}^{p} \boldsymbol{J}_{\theta j}^{T} \boldsymbol{R}_{j} \boldsymbol{J}_{\theta j}\right) \ddot{\boldsymbol{\theta}}+\left(\sum_{j=1}^{p} \boldsymbol{J}_{\theta j}^{T} \boldsymbol{R}_{j} \boldsymbol{J}_{e j}\right) \ddot{\boldsymbol{e}} \\
& +\frac{d}{d t}\left(\sum_{j=1}^{p} \boldsymbol{J}_{\theta j}^{T} \boldsymbol{R}_{j} \boldsymbol{J}_{j}\right) \dot{\boldsymbol{q}}-\frac{1}{2} \frac{\partial}{\partial \boldsymbol{\theta}} \sum_{j=1}^{p}\left(\dot{\boldsymbol{q}}^{T} \boldsymbol{J}_{j}^{T} \boldsymbol{R}_{j} \boldsymbol{J}_{j} \dot{\boldsymbol{q}}\right) \\
& -\sum_{j=1}^{p}\left(\boldsymbol{J}_{\theta j}^{T} m_{j} \boldsymbol{g}_{6}\right)
\end{aligned}
$$

となる.ただし

$$
\boldsymbol{R}_{a}=\left[\begin{array}{ccc}
I_{a 1} & 0 \\
& \ddots & \\
0 & & I_{a n}
\end{array}\right]
$$

とする.

式(30)の第 1～3 項は一般化座標の加速度によって発生する
慣性力の項, 第 4,5 項は遠心力，コリオリ力など非線形の速度 依存力の項，第 6 項は重力項である．これを考慮し，式(30)を まとめると次式を得る.

$$
\tau=M_{11}(\theta, e) \ddot{\theta}+M_{12}(\theta, e) \ddot{e}+h_{1}(\theta, \dot{\theta}, e, \dot{e})+g_{1}(\theta, e)
$$

\section{2 フィールド運動方程式}

フィールド運動方程式(22)も同様に展開できる. 式(22)に式 （20）の $L$ を代入し，式(13)を考慮し整理すると，各項は

$$
\begin{gathered}
\frac{d}{d t}\left(\frac{\partial L}{\partial \dot{e}_{l}}\right)=\sum_{j=P_{l} e^{e}}^{p}\left(\boldsymbol{j}_{e j l}^{T} \boldsymbol{R}_{j} \boldsymbol{J}_{j}\right) \ddot{\boldsymbol{q}} \\
+\sum_{j=P_{l} e}^{p} \frac{d}{d t}\left(\boldsymbol{j}_{e j l}^{T} \boldsymbol{R}_{j} \boldsymbol{J}_{j}\right) \dot{\boldsymbol{q}} \\
\frac{\partial L}{\partial e_{l}}=\frac{1}{2} \frac{\partial}{\partial e_{l}} \sum_{j=P_{l} \boldsymbol{e}}^{p}\left(\dot{\boldsymbol{q}}^{T} \boldsymbol{J}_{j}^{T} \boldsymbol{R}_{j} \boldsymbol{J}_{j} \dot{\boldsymbol{q}}\right)+\sum_{j=P_{l} \boldsymbol{e}}^{p} \frac{\partial \boldsymbol{r}_{j}^{T}}{\partial e_{l}} m_{j} \boldsymbol{g} \\
-\frac{\partial \boldsymbol{e}^{T}}{\partial e_{l}} \boldsymbol{K e}
\end{gathered}
$$

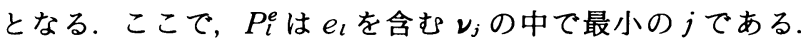
すなわち， $e_{l}$ を含むフィールドのエンドエフェク夕側にあっ て，そのフィールドに最も近いステーションの番号である.こ こて

$$
\boldsymbol{j}_{e j l}=\left[\begin{array}{c}
\boldsymbol{j}_{e j l}^{v} \\
\boldsymbol{j}_{e j l}^{\omega}
\end{array}\right]
$$

とすると，

$$
\frac{\partial \boldsymbol{r}_{j}^{T}}{\partial e_{l}}=\boldsymbol{j}_{e j l}^{v T}
$$

であるから，

$$
\frac{\partial \boldsymbol{r}_{j}^{T}}{\partial e_{l}} m_{j} \boldsymbol{g}=\boldsymbol{j}_{e_{i l}}^{T} m_{j} \boldsymbol{g}_{6}
$$

となる，式(33)，（34），(37)から式(22)は

$$
\begin{aligned}
0= & \sum_{j=P_{l} e}^{p}\left(\boldsymbol{j}_{e j l}^{T} \boldsymbol{R}_{j} \boldsymbol{J}_{j}\right) \ddot{\boldsymbol{q}}+\sum_{j=P_{l}^{e}}^{p} \frac{d}{d t}\left(j_{e j l}^{T} \boldsymbol{R}_{j} \boldsymbol{J}_{j}\right) \dot{\boldsymbol{q}} \\
& -\frac{1}{2} \frac{\partial}{\partial e_{l}} \sum_{j=P_{l} e}^{p}\left(\dot{\boldsymbol{q}}_{j}^{T} \boldsymbol{J}_{j}^{T} \boldsymbol{R}_{j} \boldsymbol{J}_{j} \dot{\boldsymbol{q}}_{j}\right)-\sum_{j=P_{l} \boldsymbol{e}}^{p}\left(\boldsymbol{j}_{e j l}^{T} m_{j} \boldsymbol{g}_{6}\right) \\
& +\frac{\partial \boldsymbol{e}^{T}}{\partial e_{l}} \boldsymbol{K} \boldsymbol{e}
\end{aligned}
$$

となる. $l=1,2, \cdots, m$ について上式をまとめると

$$
\begin{aligned}
\mathbf{0}= & \left(\sum_{j=1}^{p} \boldsymbol{J}_{e j}^{T} \boldsymbol{R}_{j} \boldsymbol{J}_{\theta j}\right) \ddot{\boldsymbol{\theta}}+\left(\sum_{j=1}^{p} \boldsymbol{J}_{e j}^{T} \boldsymbol{R}_{j} \boldsymbol{J}_{e j}\right) \ddot{\boldsymbol{e}} \\
& +\frac{d}{d t}\left(\sum_{j=1}^{p} \boldsymbol{J}_{e j}^{T} \boldsymbol{R}_{j} \boldsymbol{J}_{j}\right) \dot{\boldsymbol{q}}-\frac{1}{2} \frac{\partial}{\partial \boldsymbol{e}} \sum_{j=1}^{p}\left(\dot{\boldsymbol{q}}^{T} \boldsymbol{J}_{j}^{T} \boldsymbol{R}_{j} \boldsymbol{J}_{j} \dot{\boldsymbol{q}}\right) \\
& -\sum_{j=1}^{p}\left(\boldsymbol{J}_{e j}^{T} m_{j} \boldsymbol{g}_{6}\right)+\boldsymbol{K} \boldsymbol{e}
\end{aligned}
$$

となる. 式(39)の第 1,2 項は一般化座標の加速度によって発生 する慣性力の項, 第 3,4 項は遠心力, コリオリ力など非線形の 速度依存力の項, 第 5 項は重力項, 第 6 項はフィールドのばね 力によって発生する復元力の項である．これを考慮し，式(39) をまとめると次式を得る.

$$
\begin{aligned}
\mathbf{0}= & \boldsymbol{M}_{21}(\boldsymbol{\theta}, \boldsymbol{e}) \ddot{\boldsymbol{\theta}}+\boldsymbol{M}_{22}(\boldsymbol{\theta}, \boldsymbol{e}) \ddot{\boldsymbol{e}}+\boldsymbol{h}_{2}(\boldsymbol{\theta}, \dot{\boldsymbol{\theta}}, \boldsymbol{e}, \dot{\boldsymbol{e}}) \\
& +\boldsymbol{g}_{2}(\boldsymbol{\theta}, \boldsymbol{e})+\boldsymbol{K e}
\end{aligned}
$$

\section{3 モ一夕運動方程式}

ジョイント $i$ のエンドエフェク夕側にあってジョイント $i に$ 隣接するフィールドをフィールド $i 1$ とする. また，フィール ド $i 1$ の両端にかかる力とモーメントを Fig. 4 のように定義す る. $\boldsymbol{f}_{i 1}, \boldsymbol{n}_{i 1}$ とたわみ変位べクトル $\boldsymbol{s}_{i 1}$ の関係は式(41)のよう 


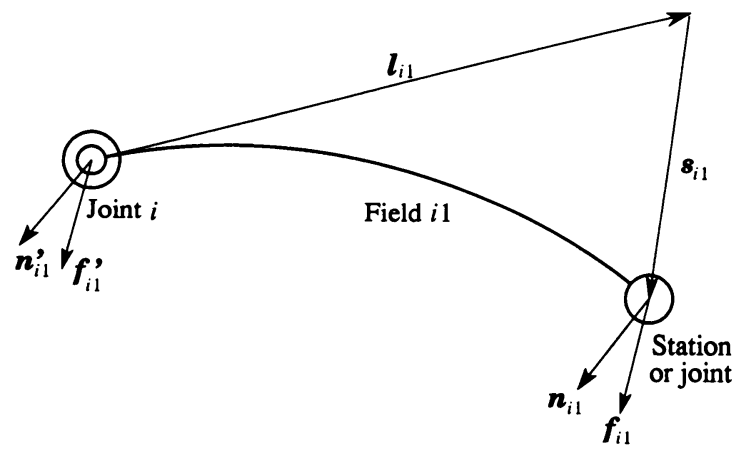

Fig. $4 i$ th field and $i$ th joint

に与えられ，次式のようになる.

$$
\left[\begin{array}{c}
\boldsymbol{f}_{i 1} \\
\boldsymbol{n}_{i 1}
\end{array}\right]=K_{i 1} S_{i 1}
$$

ジョイント $i$ にかかるモーメント $\boldsymbol{n}_{i 1}^{\prime}$ はモーメントのつりあ いから次式のように求められる.

$$
\boldsymbol{n}_{i 1}^{\prime}=\boldsymbol{n}_{i 1}+\boldsymbol{l}_{i 1} \times \boldsymbol{f}_{i 1}
$$

ここで， $\boldsymbol{l}_{i 1}$ は座標系 $\sum_{i 1}$ における $\sum_{i 1}^{\prime}$ の原点の位置べクトル である. 問題を簡単にするため, ここではジョイント $i$ の回転 方向に $z_{i 1}$ 軸をとり， $\boldsymbol{l}_{i 1}$ 方向に $x_{i 1}$ 軸をとる. このように座標 系を設定した場合， $\boldsymbol{l}_{i 1}$ は

$$
l_{i 1}=\left[\begin{array}{lll}
l_{i 1} & 0 & 0
\end{array}\right]^{T}
$$

となる.

さて，式(41)，(42)，(43)から $\boldsymbol{n}_{\boldsymbol{i 1}}^{\prime}$ をつぎのように表すこと ができる.

$$
\boldsymbol{n}_{i 1}^{\prime}=\boldsymbol{Z}_{i 1} \boldsymbol{K}_{i 1} \boldsymbol{s}_{i 1}
$$

ただし，

$$
\boldsymbol{Z}_{i 1}=\left[\begin{array}{cccccc}
0 & 0 & 0 & 1 & 0 & 0 \\
0 & 0 & -l_{i 1} & 0 & 1 & 0 \\
0 & l_{i 1} & 0 & 0 & 0 & 1
\end{array}\right]
$$

とする.

ジョイント $i$ が発生すべきトルク $\tau_{i}$ はアクチュエータのロ 一夕部の慣性モーメント $I_{a i}$ を考慮すると

$$
\tau_{i}=I_{a i} \ddot{\theta}_{i}-\left[\begin{array}{lll}
0 & 0 & 1
\end{array}\right] \boldsymbol{n}_{i 1}^{\prime}
$$

である. 式(44)，(46)から， $\tau_{i}$ はつぎのように表すことができる.

$$
\tau_{i}=I_{a i} \ddot{\theta}_{i}-\boldsymbol{W}_{i 1} \boldsymbol{K}_{i 1} \boldsymbol{s}_{i 1}
$$

$\boldsymbol{s}_{i 1}$ を 6 次元のべクトルとしたとき， $\boldsymbol{W}_{i 1}$ は $1 \times 6$ の行列とな る. 式(47)から， $\tau_{i}$ は弾性変位べクトル $\boldsymbol{s}_{i 1}$ とフィールドに固 有のばね定数を表す行列 $\boldsymbol{K}_{i 1}$ から算出できることがわかる，i $=1,2, \cdots, n$ について式(47)をまとめると

$$
\boldsymbol{\tau}=\boldsymbol{R}_{a} \ddot{\boldsymbol{\theta}}-\boldsymbol{W K e}
$$

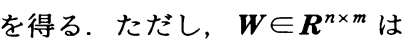

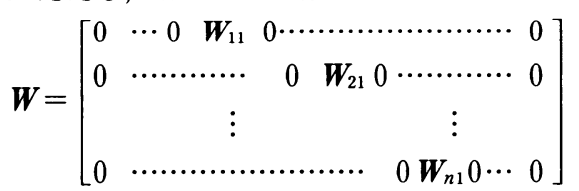

で表される行列である。式(48)をモー夕運動方程式と呼ぶこと にする.

式(44)，(46)，(47)，(49)から一般には $\boldsymbol{W}$ は定数行列とな る.しかし，実際にはフィールド $k$ の弾性変位ベクトル $\boldsymbol{s}_{k}$ が
定義できない場合がある. 例えば，ジョイント $i$ とジョイント $i+1$ が同一点に存在すると仮定し, ジョイント $i$ とジョイン ト $i+1$ を結合しているフィールド $i 1$ に対し，その長さ $l_{i 1}$ を 0 とし，そのばね定数を無限大と仮定した場合などがこれに相 当する.このとき, 式(44)が成り立たなくなる.このような場 合, ジョイント $i+1$ に隣接するエンドエフェクタ側のフィー ルド $(i+1) 1$ の弾性変位ベクトル $\boldsymbol{s}_{(i+1) 1}$ より,

$$
\boldsymbol{n}_{i 1}^{\prime}=\boldsymbol{A}_{i+1} \boldsymbol{n}_{(i+1) 1}^{\prime}
$$

なる関係を利用して,

$$
\boldsymbol{n}_{i 1}^{\prime}=\boldsymbol{A}_{i+1} \boldsymbol{Z}_{(i+1) 1} \boldsymbol{K}_{(i+1) 1} \boldsymbol{s}_{(i+1) 1}
$$

からモー夕運動方程式を構築することができる． $\boldsymbol{s}_{(i+1) 1}$ が定義 できない場合には，同様に，式(50)を順次適用していく．この とき, $\boldsymbol{n}_{i 1}^{\prime}$ が $\boldsymbol{\theta}$ の関数となり，式(46)，(47), (49)から, $\boldsymbol{W}$ は姿勢に依存した行列となる，なお，本節で導いたモー夕運動 方程式は，式(32)，（40)において項の消去を行うことにより導 くこともできる[13].

\section{5. 考察}

フレキシブルマニピュレータの運動方程式がリンク運動方程 式とフィールド運動方程式で表されることを示した. また，こ の二つの運動方程式をまとめた形の運動方程式として, モー夕 運動方程式を導いた。 以下，これらの運動方程式について考察 する.

リンク運動方程式 (30)で $\ddot{\boldsymbol{e}}=\dot{\boldsymbol{e}}=\boldsymbol{e}=\mathbf{0}$ とおくと

$$
\begin{aligned}
\boldsymbol{\tau}= & \boldsymbol{R}_{a} \ddot{\boldsymbol{\theta}}+\left(\sum_{j=1}^{p} \boldsymbol{J}_{\theta j}^{T} \boldsymbol{R}_{j} \boldsymbol{J}_{\theta j}\right) \ddot{\boldsymbol{\theta}}+\frac{d}{d t}\left(\sum_{j=1}^{p} \boldsymbol{J}_{\theta j}^{T} \boldsymbol{R}_{j} \boldsymbol{J}_{\theta j}\right) \dot{\boldsymbol{\theta}} \\
& -\frac{1}{2} \frac{\partial}{\partial \boldsymbol{\theta}} \sum_{j=1}^{p}\left(\dot{\boldsymbol{\theta}}^{T} \boldsymbol{J}_{\theta j}^{T} \boldsymbol{R}_{j} \boldsymbol{J}_{\theta j} \dot{\boldsymbol{\theta}}\right)-\sum_{j=1}^{p}\left(\boldsymbol{J}_{\theta j}^{T} m_{j} \boldsymbol{g}_{6}\right)
\end{aligned}
$$

を得る.これは, 剛体マニピュレータの運動方程式を表す.す なわち, リンク運動方程式が剛体マニピュレータの運動方程式 の自然な拡張であることがわかる.

また，このとき，フィールド運動方程式 (39) は式 ( 2 )を考慮 に入れると，

$$
\begin{aligned}
\mathbf{0}= & \left(\sum_{j=1}^{p} \boldsymbol{J}_{e j}^{T} \boldsymbol{R}_{j} \boldsymbol{J}_{\theta j}\right) \ddot{\boldsymbol{\theta}}+\frac{d}{d t}\left(\sum_{j=1}^{p} \boldsymbol{J}_{e j}^{T} \boldsymbol{R}_{j} \boldsymbol{J}_{\theta j}\right) \dot{\boldsymbol{\theta}} \\
& -\frac{1}{2} \frac{\partial}{\partial \boldsymbol{e}} \sum_{j=1}^{p}\left(\dot{\boldsymbol{\theta}}^{T} \boldsymbol{J}_{\theta j}^{T} \boldsymbol{R}_{j} \boldsymbol{J}_{\theta j} \dot{\boldsymbol{\theta}}\right) \\
& -\sum_{j=1}^{p}\left(\boldsymbol{J}_{e j}^{T} m_{j} \boldsymbol{g}_{6}\right)+\left[\begin{array}{c}
\boldsymbol{f}_{1} \\
\boldsymbol{n}_{1} \\
\vdots \\
\boldsymbol{f}_{q} \\
\boldsymbol{n}_{q}
\end{array}\right]
\end{aligned}
$$

となる. 式(53)を解くことにより，リンク各部に加わる力とモ ーメントを得る. 式(53)はいままで剛体マニピュレータでは考 慮されていない. 剛体リンクの仮想的な弾性変位を考えること で各リンクの力とモーメントが計算できるということは非常に 興味深い.

以上，本論文で導いたリンク運動方程式，フィールド運動方 程式で剛体マニピュレータ及びフレキシブルマニピュレータの 運動方程式を統一的に論じることが可能であることを示した. 剛体マニピュレータはフレキシブルマニピュレータのある特殊 な形態であると考えることができる. 
最後にモー夕運動方程式について考察する．モー夕運動方程 式(48) はモータの回転部の慣性負荷を除けば, 慣性力項, 遠心 力及びコリオリカの項, 重力項などのステーションの慣性によ って発生する力の項が表面には現れない.これらの項はすべ て，各ジョイントに直結するフィールドの復元力として表現さ れる．運動方程式をこのような簡潔な形にまとめることができ るのは, 各ジョイントに直結するフィールドの弾性変形が, そ れらのジョイントにかかる力とモーメントに対応しているから である. 多くのトルクセンサは，モータの出力軸に弾性部分を 設け，その弾性歪みを測定することでトルクを検出している が，これは言い換えれば，モータの出力軸にフィールドを取り 付け，そのフィールドの弾性変位を測定していることにほかな らない.

\section{6. 適 用 例}

以上の理論を実際の実験機に適用する，モデルを作成し，モ デルに基づいたシミュレーション結果と実験機による実験結果 を比較することでモデルの妥当性を検証する．簡便のため， ス テーションの慣性モーメントはここでは考慮しない. ステーシ ヨンの慣性モーメントを考慮しない簡略化された運動方程式は

$$
\begin{aligned}
\boldsymbol{\tau}= & \boldsymbol{R}_{a} \ddot{\boldsymbol{\theta}}+\left(\sum_{j=1}^{p} m_{j} \boldsymbol{J}_{\theta j}^{v T} \boldsymbol{J}_{\theta j}^{v}\right) \ddot{\boldsymbol{\theta}}+\left(\sum_{j=1}^{p} m_{j} \boldsymbol{J}_{\theta j}^{v T} \boldsymbol{J}_{e j}^{v}\right) \ddot{\boldsymbol{e}} \\
& +\frac{d}{d t}\left(\sum_{j=1}^{p} m_{j} \boldsymbol{J}_{\theta j}^{v T} \boldsymbol{J}_{j}^{v}\right) \dot{\boldsymbol{q}}-\frac{1}{2} \frac{\partial}{\partial \boldsymbol{\theta}} \sum_{j=1}^{p} m_{j}\left(\dot{\boldsymbol{q}}^{T} \boldsymbol{J}_{j}^{v T} \boldsymbol{J}_{j}^{v} \dot{\boldsymbol{q}}\right) \\
& -\sum_{j=1}^{p}\left(\boldsymbol{J}_{\theta j}^{v T} m_{j} \boldsymbol{g}\right) \\
\mathbf{0}= & \left(\sum_{j=1}^{p} m_{j} \boldsymbol{J}_{e j}^{v T} \boldsymbol{J}_{\theta j}^{v}\right) \ddot{\boldsymbol{\theta}}+\left(\sum_{j=1}^{p} m_{j} \boldsymbol{J}_{e j}^{v T} \boldsymbol{J}_{e j}^{v}\right) \ddot{\boldsymbol{e}} \\
& +\frac{d}{d t}\left(\sum_{j=1}^{p} m_{j} \boldsymbol{J}_{e j}^{v T} \boldsymbol{J}_{j}^{v}\right) \dot{\boldsymbol{q}}-\frac{1}{2} \frac{\partial}{\partial \boldsymbol{e}} \sum_{j=1}^{p} m_{j}\left(\dot{\boldsymbol{q}}^{T} \boldsymbol{J}_{j}^{v T} \boldsymbol{J}_{j}^{v} \dot{\boldsymbol{q}}\right) \\
& -\sum_{j=1}^{p}\left(\boldsymbol{J}_{e j}^{v T} m_{j} \boldsymbol{g}\right)+\boldsymbol{K} \boldsymbol{e}
\end{aligned}
$$

となる，以下，式(54)，（55）を用いて議論を進める.

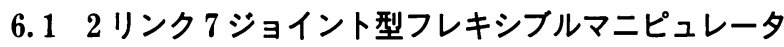
当研究室と(株)富士通研究所で共同開発した 2 リンク 7 ジョ イント型フレキシブルマニピュレータ ADAM[16] のモデルを

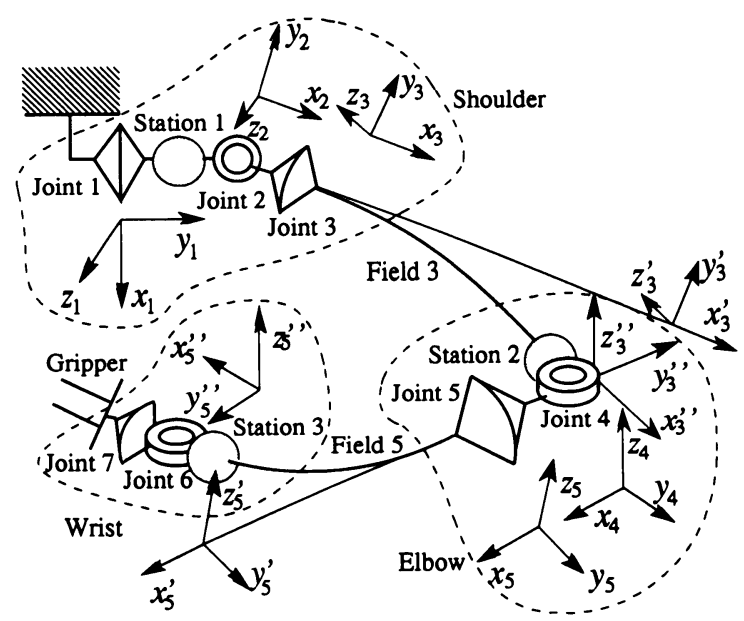

Fig. 5 Model of the experimental robot ADAM
Fig. 5 のように作成する. Fig. 5 で点線で囲った部分は同一箇 所に存在することを示す。実験機 ADAM は大きく分けて shoulder module, elbow module, wrist module の三つのモジ ュールとそれらをつなぐアームから構成されている. 今回はそ れぞれのアームをひとつのフィールドとし，各モジュールにひ とつずつステーションが存在するようなモデルを作成した.

実験機 ADAM は 7 ジョイントを有しているが, エンドエフ エクタの位置に直接関与するのはジョイント 1〜4 4ので, こ れらをジョイント角度べクトルと考える. ジョイントトルクベ クトル $\tau$ とジョイント角度べクトル $\boldsymbol{\theta}$, たわみ変位べクトル $\boldsymbol{e}$ をそれぞれつぎのようにとる.

$$
\begin{gathered}
\boldsymbol{\tau}=\left[\begin{array}{llll}
\tau_{1} & \tau_{2} & \tau_{3} & \tau_{4}
\end{array}\right]^{T} \\
\boldsymbol{\theta}=\left[\begin{array}{llll}
\theta_{1} & \theta_{2} & \theta_{3} & \theta_{4}
\end{array}\right]^{T} \\
\boldsymbol{e}=\left[\begin{array}{llll}
\delta_{y 3} & \delta_{z 3} & \delta_{y 5} & \delta_{z 5}
\end{array}\right]^{T}
\end{gathered}
$$

ただし， $\delta_{y 3}, \delta_{z 3}, \delta_{y 5}, \delta_{z 5}$ はそれぞれフィールド $3 ， 5$ の $y$, $z$ 軸方向のたわみである. たわみ変位べクトル $\boldsymbol{e}$ の要素とし て, 各座標軸回りのたわみ角変位 $\phi_{x 3}, \phi_{y 3}, \phi_{z 3}, \phi_{x 5}, \phi_{y 5}$, $\phi_{z 5}$ も考えられるが，本節のモデルではステーションの慣性モ 一メントを考慮していないため, $\delta_{y 2}, \delta_{z 2}, \delta_{y 3}, \delta_{z 3}$ に従属な 変数となる $[11]$.また, フィールドの軸方向の変位 $\delta_{x 2}, \delta_{x 3}$ は微小であるとし，eには含めない.

作成したモデルに基づき，式(54)，（55)より運動方程式を計 算する．計算に用いる各パラメータについては，実験機の特性 值をそのまま用いることにする．このことにより，モデル化誤 差が大きくなると考えられるが，モデル化誤差を小さくするた めには，ステーションの数を増やし実験機により近いモデルを 構築すればよい，運動方程式で用いた各パラメー夕を Table 1 に示す. Field 3, 5 に相当する実験機のリンクの質量はそれぞ れ, $0.7[\mathrm{~kg}], 0.5[\mathrm{~kg}]$ であるが，この質量を 2 分し，両端の関 節部の質量にそれぞれ付加し，ステーションの質量とした.

\section{2 シミュレーション及び実験}

実験機 ADAM は速度指令型のマニピュレータであるた め, これに合わせて, シミュレーションも速度指令型とした. このシミュレータではつぎのような近似式を用いて，速度指令 から入カトルクを作成する.

$$
\boldsymbol{\tau}=\boldsymbol{G}_{r} \boldsymbol{K}_{s p}\left(\boldsymbol{V}_{r e f}-\boldsymbol{K}_{s v} \dot{\boldsymbol{\theta}}_{m}\right)
$$

ここで， $\tau$ はシミュレータへの入力トルクベクトル， $G_{r}$ はモ

Table 1 Parameters in the equations of motion

\begin{tabular}{l|c|c}
\hline Parameter & Notation & Value \\
\hline Length of fields & $l_{3}[\mathrm{~m}]$ & 0.50 \\
& $l_{5}[\mathrm{~m}]$ & 0.50 \\
\hline Bending stiffness & $E_{3} I_{3}\left[\mathrm{Nm}^{2}\right]$ & 291.6 \\
of fields & $E_{5} I_{5}\left[\mathrm{Nm}^{2}\right]$ & 102.1 \\
\hline Mass of stations & $m_{2}[\mathrm{~kg}]$ & 6.6 \\
& $m_{3}[\mathrm{~kg}]$ & 3.0 \\
\hline Rotor's inertia & $I_{m 1}\left[\mathrm{Nms}^{2}\right]$ & $1.63 \times 10^{-4}$ \\
& $I_{m 2}\left[\mathrm{Nms}^{2}\right]$ & $0.99 \times 10^{-4}$ \\
& $I_{m 3}\left[\mathrm{Nms}^{2}\right]$ & $0.99 \times 10^{-4}$ \\
& $I_{m 4}\left[\mathrm{Nms}^{2}\right]$ & $0.15 \times 10^{-4}$ \\
\hline
\end{tabular}




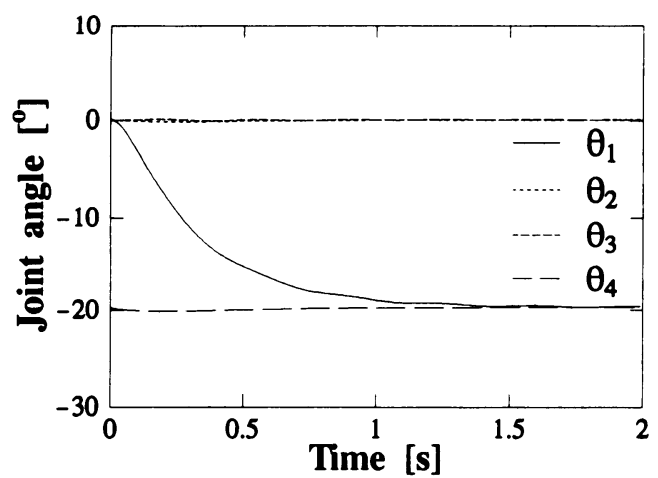

(a) Joint responses

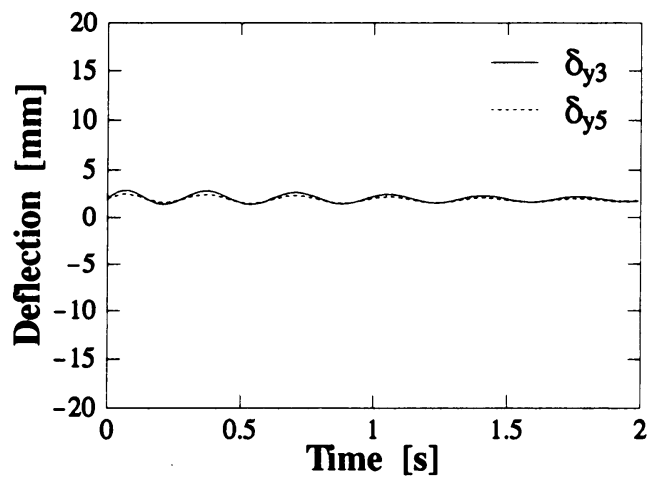

(b) Tip displacement in the $y$ direction

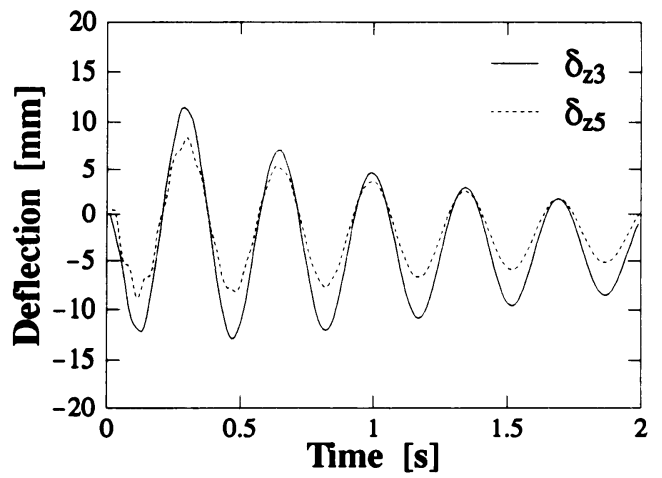

(c) Tip displacement in the $z$ direction

Fig. 6 Simulation results

一夕の減速比行列, $\boldsymbol{K}_{s p}$ は速度フィードバックゲイン行列, $\boldsymbol{V}_{\text {ref }}$ はアンプに入力する速度指令入力ベクトル， $\dot{\boldsymbol{\theta}}_{m}$ はモー夕 の減速前の回転角速度べクトルである．実際の実験機では $V_{r e f}$ はー10〜10[V]の電圧で表現され，モータが無負荷の状態で 9 $[\mathrm{V}]$ の入力に対し $3000[\mathrm{rpm}]$ の出力が得られるように $\boldsymbol{K}_{s v}$ が 調整されている. シミュレーションでは $\boldsymbol{G}_{r}=\operatorname{diag}\left[\begin{array}{ll}100 & 100\end{array}\right.$ $100100]$ とし， $\boldsymbol{K}_{s p}$ はシミュレーション結果が実験結果に近い ものになるように調整した.

シミュレータでは 4 次の Runge-Kutta-Gill 法による積分を 用いた。積分のきざみ幅は $0.1[\mathrm{~ms}]$ とした。 また，式(59)で 記述される速度フィードバックを $1[\mathrm{~ms}]$ ごとに行った. シミ ュレーションのサンプリング時間は実験機による実験と同じ $10[\mathrm{~ms}]$ とした.

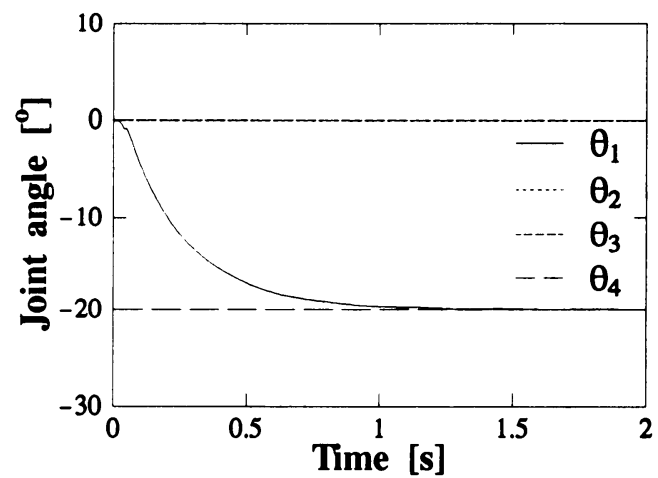

(a) Joint responses

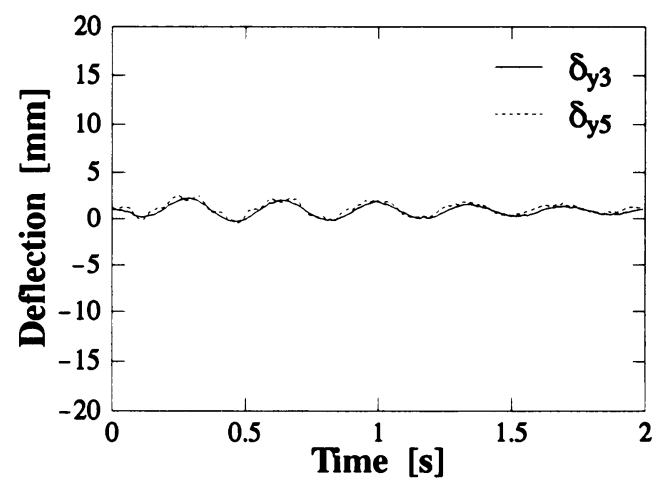

(b) Tip displacement in the $y$ direction

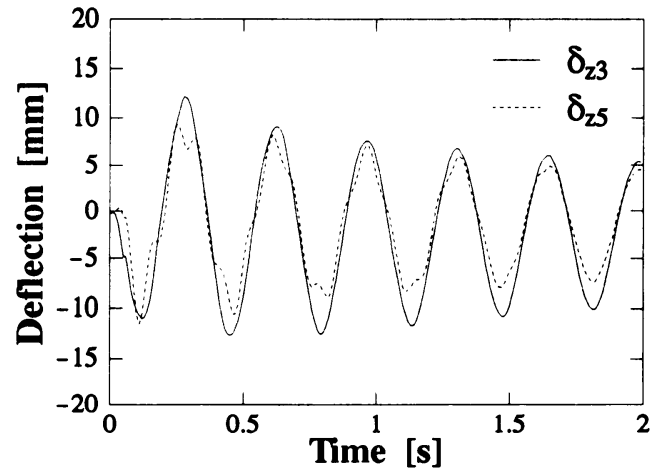

(c) Tip displacement in the $z$ direction

Fig. 7 Experimental results

目標位置のステップ入力に対する応答実験をシミュレータ, 及び実験機を用いて行い，その応答を比較する。制御則は簡単 な $\mathrm{P}$ 制御で，位置制御ゲインはシミュレータ，実験共に 4.0 $\left[\mathrm{s}^{-1}\right]$ をえた。シシュレーション結果及び実験結果をそれぞ れ Fig. 6, 7 に示す.

シミュレーション結果では実験結果に比べて, アームの振動 の減衰が早くなっているが，これはシミュレータが実験機の速 度指令型アンプの特性を完全にはシミュレートできていないた めであると思われる.

本節で作成したモデルは，簡便のため関節部の慣性モーメン トを無視したこと，実験機の関節部の質量に比べてリンクの質 量が小さいことなどから, 吉川, 村上, 細田のモデル[11]と結 果的に，ほほ同一のモデルとなった(本論文ではリンクの質量 
を考慮した点が異なる). しかしながら，本論文のモデリング 手法ではステーションの数を増やすことや，ステーションの慣 性モーメントを考慮することで, より精度の高い近似モデルを 作成することが可能である，関節部の質量に比べてリンクの質 量が無視できないぐらい大きい場合やリンクの柔軟性が非常に 大きく高次モードの考慮が必要な場合などに, 本手法の優位性 が示せるものと思われる.

\section{7. おわりに}

機械振動学でよく知られた Holzer 法による柔軟構造物のモ デル化手法をフレキシブルマニピュレータに適用し, 運動学と の関連が明確で，非常に見通しの良いモデルを導出した．この モデルに基づきリンク運動方程式, フィールド運動方程式, モ 一夕運動方程式を導いた。 そして, これらの運動方程式に考察 を加え, フレキシブルマニピュレータと剛体マニピュレータの 関連性について論じ, これらのマニピュレータを統一的に論じ ることの可能性を示唆した。 なお，本論文で導いたリンク運動 方程式, フィールド運動方程式, モー夕運動方程式は本モデリ ング手法に固有のものではなく，どのようなモデリング手法を 用いても導くことができる.

筆者らは, このモデルをフレキシブルアームの振動抑制制御 法に適用し，その有効性を検証した $[17]$. またこのモデルを用 いて，モード可到達性の概念を論じた[18].しかし，筆者らは 本モデルの適用範囲はこれだけに限定されず, 逆運動学, 逆動 力学の解法 [19]. アームの運動学 $[20]$ など, 広範囲の応用が可 能であると考えている.

\section{参 考 文 献}

[1] “フレキシブルアーム特集”, 日本ロボット学会誌, vol. 6, no. 5, 1988.

[2] R. H. Cannon Jr. and E. Schmitz: "Initial experiments on the end-point control of a flexible one-link robot," Int. J. of Robotics Research, vol. 3, no. 3, pp. 62-75, 1984.

[3] W. H. Sunada and S. Dubowsky: "On the dynamic analysis and behavior of industrial robotic manipulators with elastic members," Trans. of ASME, J. of Mechanisms, Transmissions, and Automation in Design, vol. 105, pp. 42-51, 1983.

[4] E. Bayo: "A finite-element approach to control the end-point motion of a single-link flexible robot," J. of Robotic Systems, vol. 4, no. 1, pp. 63-75, 1987.
[5] 内山勝: “ロポットのダイナミックス”, 機械の研究, vol. 36, no. 1, pp. 131-136, 1984.

[6 ] 姜兆慧：“フレキシブルロボットアームの制御に関する研究”, $\mathrm{PhD}$ thesis, 東北大学, 1988 .

[ 7] 山田克彦：“宇宙多体システムの定式化とその制御への応用”, PhD thesis, 東京大学, 1989 .

[8] 坂和愛幸, 松野文俊, 大澤善樹, 清原誠, 阿部敏久: “3 自由度フレ キシブル・マニピュレータのモデリングと加速度センサを用いた振動 制御”, 日本ロボット学会誌, vol. 6, no. 1, pp. 42-51, 1988.

[9] 下山勲, 三浦宏文: “静たわみ曲線を用いたフレキシブルアームの動 力学モデル”, 日本ロボット学会誌, vol. 6, no. 5, pp. 436-442, 1988.

[10] Y. Huang and C. S. G. Lee: "Generalization of newton-euler formulation of dynamic equations to nonrigid manipulators," Trans. of ASME, J. of Dynamic Systems, Measurement and Control, vol. 110, pp. 308-315, 1988.

[11] 吉川恒夫, 村上弘記, 細田耕：“2 本のフレキシブルリンクを有する 3 自由度マニピュレータのモデリンク゚と制御”, 日本ロボット学会誌, vol. 9, no. 1, pp. 1-10, 1991.

[12］吉川恒夫, 細田耕：“仮想的な剛体リンクと受動関節を用いたフレキ シブルアームのモデリング”, 計測自動制御学会論文集, vol. 27 , no. 12, pp. 1389-1395, 1991.

[13] 内山勝, 近野敦 : “ホルツァ法に基づくフレキシブルアームの動力学 モデリング”, 日本ロボット学会第 1 回ロボットシンポジウム予稿集, pp. 247-252, 1991.

[14] L. Meirovitch : "Analytical Methods in Vibrations," Macmillan Publishing Co., Inc., 1967.

[15）デンハルトック, (谷口修, 藤井澄二共訳) : “機械振動論 (改訂版)”, コロナ社, 1960 .

[16] M. Uchiyama, A. Konno, T. Uchiyama, and S. Kanda : "Development of a flexible dual-arm manipulator testbed for space robotics," In Proc. of IEEE Int. Workshop on Intelligent Robots and Systems ' 90, pp. 375-381, Tsuchiura, Japan, 1990.

[17] A. Konno and M. Uchiyama: "Configuration-dependent vibration control of multi-link spatial flexible manipulators," In T. Takamori and K. Tsuchiya, editors, Robotics, Mechatronics and Manufacturing Systems, pp. 937-942 : Elsevier Science Publishers B. V. (North-Holland), 1993.

[18] A. Konno, M. Uchiyama, Y. Kito, and M. Murakami : "Vibration controllability of flexible manipulators," In Proc. of IEEE Int. Conf. on Robotics and Automation, pp. 308-314, San Diego, USA, 1994.

[19] E. Bayo, P. Papadopoulos, J. Stubbe, and M. A. Serna: "Inverse dynamics and kinematics of multi-link elastic robots: An interative frequency domain approach," Int. J. of Robotics Research, vol. 8, no. 6, pp. 49-62, 1989.

[20］姜兆慧, 内山勝：“フレキシブルロボットアームの可補償性”, 日本口 ボット学会誌, vol. 6 , no. 5 , pp. 416-423, 1988.

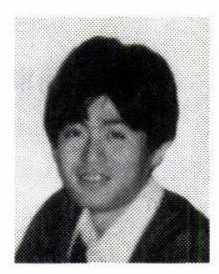

\section{近野 敦 (Atsushi Konno)}

1966 年 1 月 4 日生. 1988 年東北大学工学部精密工 学科卒業. 1993 年同大学大学院博士課程修了, 博 士. 同年東北大学工学部機械航空工学科助手. 現 在フレキシブルマニピュレータなどの研究に従 事. (日本ロボット学会正会員)

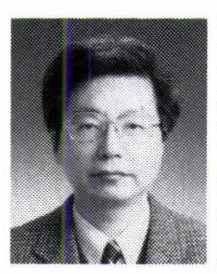

内山 勝 (Masaru Uchiyama)

1949 年 9 月 16 日生. 1972 年東京大学工学部産業 機械工学科卒業, 1977 年同大学大学院博士課程修 了, 工学博士. 同年東北大学工学部精密工学科助 手, 1980 年同助教授, 1992 年同学部機械航空工学 科教授, 宇宙機械学講座を担当. 宇宙ロボットの 研究, 教育に従事. 日本航空宇宙学会北部支部幹事.

(日本ロボット学会正会員) 